\title{
How Does Foreign Equity Right Impact Manufacturing Enterprise Innovation Behaviors? Mediation Test Based on Technology Introduction
}

\author{
Shan Cen, Lianshui Li, and Weijun Cui 1 (D \\ School of Business, Nanjing University of Information Science \& Technology, Nanjing 210044, China \\ Correspondence should be addressed to Weijun Cui; 000928@nuist.edu.cn
}

Received 11 May 2020; Accepted 25 June 2020; Published 17 July 2020

Guest Editor: Lin-Yun He

Copyright (c) 2020 Shan Cen et al. This is an open access article distributed under the Creative Commons Attribution License, which permits unrestricted use, distribution, and reproduction in any medium, provided the original work is properly cited.

\begin{abstract}
The impacts of FDI (foreign direct investment) on the innovation of Chinese local enterprises have always been the focus of attention, but few studies have explored the impacts of foreign shareholding on enterprise innovation behaviors through the micro level. Based on the survey data regarding the manufacturing sector of China enterprises conducted by the World Bank in 2012, this paper conducts an empirical study on the relationship between foreign shareholding and enterprise innovation behaviors. The research findings include two aspects; that is, (1) foreign shareholding has significantly positive impacts on enterprise innovation behaviors; (2) technology introduction plays a complete mediating effect in foreign shareholding and enterprise innovation behaviors. On the basis of considering sample selective bias and endogenous problems, the propensity score matching (PSM) method is further applied to evaluate the impacts of foreign shareholding on enterprise innovation behaviors. After putting the endogenous problems and sample selective bias under control, the above conclusions are still robust. Thus, under the current complicated international situation, enterprises should be encouraged to attract foreign investment under moderate control, with a view to accelerating the promotion of enterprise innovation activities through the technology introduction brought about by foreign shareholding.
\end{abstract}

\section{Introduction}

Since 2018, Sino-US trade frictions have intensified, and the entry of foreign capital and technology transfer have become hot topics of extensive discussion. Along with the gradual deepening of reform and opening up and the continuous reform of economic system, a large amount of foreign capital has poured into the Chinese capital market. From the initial form of joint venture, it has gradually changed into direct investment and then the equity participation in domestic listed companies. Foreign capital has more and more channels and opportunities to enter the Chinese market, thus posing increasingly profound impacts on Chinese companies and the market. For China, it is hoped that advanced technology can be brought to enterprises through the introduction of foreign capital, so as to promote the enterprise innovation and industrial upgrading and achieve high-quality economic development. According to the Ministry of Commerce, China's actual use of foreign capital in 2019 amounted to CNY 941.52 billion, hitting up to nearly $6 \%$ on year-on-year basis and creating a record high. In the 2019 government work report, it is also clearly proposed to continue the deepening of reform, expansion of opening up, and introduction of more open policies to attract foreign capital. As a result, foreign capital seems to have become one of the most important factors affecting the new round of development and reform of Chinese enterprises.

From a theoretical point of view, by making a comprehensive survey on the existing literature, despite the fact that some scholars have paid attention to the relationship between entry of foreign capital and innovation, they basically concentrated on the impacts of foreign direct investment (abbreviated as FDI), and most studies are conducted from the industrial or regional perspectives, judging the impacts of FDI on Chinese enterprises via the total-factor productivity. Based on studies at the industry level, scholars believe that FDI can impact the innovation of Chinese enterprises through competition effect, 
demonstration effect, talent flow effect, and industry correlation effect [1]. Other scholars use interprovincial data to explore the regional innovation effect brought by the entry of foreign capital and drew four different conclusions: foreign capital promotes regional innovation, foreign capital hinders regional innovation, there is no significant relationship between the two, and there are certain situational conditions (such as absorption capacity of host country, geographical location, etc.) [2-5]. However, few researches have focused on the impacts of foreign shareholding on the innovation of invested companies from the perspective of individual companies at the micro level, possibly due to the limitation of microdata availability.

From a practical point of view, as a successful economic power in transformation, China's market-oriented reform and enterprise restructuring have made some enterprises experience pains, but the results are remarkable. Will these characteristics of economic system transformation make Chinese manufacturing enterprises excessively cautious when absorbing foreign capital? Under the background of marketoriented reform, foreign capital, as an important source of external technology, will undoubtedly exert an important influence on China's economy. However, after the trade friction between China and the United States, the relationship between the two sides is tense, and there are still big disputes among people from all walks of life over whether to continue to vigorously introduce foreign investment and other issues. Through the analysis of the impact of foreign equity right (FER) on Chinese manufacturing enterprises and the impact path, it can help Chinese manufacturing enterprises make more efficient use of foreign capital, help China to further accelerate the reform of economic system and further open the market at home and abroad, and accelerate the development of innovation drive, and then activating the vitality of the market economy development provides new empirical evidence and provides the basis for further introduction of foreign investment policy.

Previous research has selected the overall industry data for their researches; thus the heterogeneity and endogeneity of enterprise are prone to be neglected and affected. Accordingly, the research conclusions obtained are also not quite similar. In order to minimize the above-mentioned adverse effects as much as possible, we generally select the enterprise microdata for thorough inquiries [6,7]. In this paper, the microenterprise data from the World Bank China Enterprise Survey 2012 is used to probe into this issue, while PSM propensity score matching method is used to rectify the sample selective bias and other possible endogenous problems. Therefore, on the basis of previous researches by scholars, this paper will focus on studies at the micro level of enterprises, with the aim to conduct an in-depth analysis regarding the impacts of entry of FER on Chinese manufacturing enterprises innovation and its effect pathway.

The possible contributions of this paper are as follows. Firstly, it helps to optimize the allocation of Chinese manufacturing enterprises equity structure and provides evidence from the micro level for the impacts of foreign capital on Chinese manufacturing enterprises innovation. Secondly, this paper has not only analyzed the role of foreign equity right in the innovation of Chinese manufacturing companies but also further examined its effect pathway, finding that FER promotes enterprise innovation by introducing newer and better technologies. Scholars have not reached unanimous conclusion on whether the entry of foreign capital can promote the enterprise innovation. Although some studies have proved that foreign investors can significantly improve the level of enterprise innovation, the reason has not been investigated [8]. As far as Chinese enterprises are concerned, most foreign investors come from developed countries usually provided with more advanced technology, corresponding management, and application technology capabilities. For this reason, Chinese enterprises can better realize the "corner overtaking" in the development of traditional advantageous industries only by making better use of late-developing advantage and integrating external resources and technologies to promote the enhancement of independent innovation capability.

\section{Literature Review and Research Hypothesis}

2.1. Foreign Shareholding and Enterprise Innovation. Based on the view of resource dependence, previous studies show that a single enterprise usually does not have all the resources required to produce innovation. The literature on corporate governance shows that foreign companies and foreign capital are key external stakeholders in emerging economies, because they can bring necessary resources and benefits to enterprise innovation activities. We believe that the impacts of foreign shareholding on enterprise innovation include several aspects as follows.

The first is potential relational network. Foreign capital can make use of its own commercial resources in the home country to facilitate the cooperation between the invested local enterprises and the home enterprises, so that the invested enterprises can learn the operating logic and corporate culture of foreign enterprises and carry out cooperative $R \& D$ with foreign enterprises $[9,10]$. This can help local enterprises create new knowledge, enhance innovation capabilities, and thus accelerate their innovation processes.

The second is the improvement of the corporate governance. In order to ensure investment returns, foreign shareholders' meeting will urge enterprises to increase R\&D inputs, and the supervisory management will pay more attention to innovation projects [11]. At the same time, due to their relatively independent positions and more objective judgments, foreign shareholders can better urge enterprises to carry out the governance structure reform, while the stability of company is directly proportional to the smooth governance and easy promotion of innovation [12].

The third is the effect of technology introduction. Foreign shareholding is often accompanied by the outputs of advanced technology and knowledge, which greatly reduces the risk, difficulty, and cost of innovative $R \& D$ and enables enterprises to obtain technological innovations within a shorter time and to a greater extent $[13,14]$.

The fourth is the effect of personnel training. In order to obtain benefits, improve the market advantage of enterprise, and occupy more market share, foreign shareholders' 
meeting may organize employees to receive professional skills training or recruit professional talents [15], while the consummation of talent training mechanism is also conducive to the enterprise innovation to a certain extent.

The fifth is solving the capital supply. Innovation is a process that requires a large amount of long-term capital investments. Due to the limitation of domestic economic development level and the imbalance of resource allocation, there are often enterprises whose process of innovation activities is affected due to the problem of capital chain [16], while the large amount of capital and complementary assets brought by foreign capital can solve the problem of capital chain faced by enterprises, alleviate the financing constraints of enterprises, and thus improve the innovation capability of enterprises [11].

Therefore, based on the above analysis, this paper proposes the research Hypothesis 1 as follows.

Hypothesis 1. Foreign shareholding has significantly positive impacts on the enterprise innovation.

\subsection{Foreign Shareholding and Technology Introduction.}

The improvement of national economic level is composed of many factors, among which technological progress is one of the most core and key factors. In the early stage of introducing foreign capital, China also put forward the slogan and strategy of "Using market share to exchange technology," and it is thus evident that the most important objective of introducing foreign capital is to expect the advanced technology brought by foreign capital to drive the technological progress of domestic enterprises. Under the general trend of global economic integration, the technological gap between developing countries and developed countries increasingly makes it difficult for developing countries to catch up with the advanced level of technology possessed by developed countries through the application of technology R\&D by following the prescribed order. Therefore, among the ways in which foreign shareholding affects the enterprise innovation, we believe that technology introduction is the most direct and effective manner.

In this case, is the introduction of foreign capital conducive to the technology introduction? Through a series of studies, scholars have found that foreign investors in companies often consolidate their strategic interests by developing the host country market. In order to gain a competitive advantage in the host country market, these foreign-shareholding companies need to have more advanced technical competence than that of local companies, and thus these foreign-shareholding companies will pay more attention to the technology introduction [12]. Meanwhile, the main appeal of domestic enterprises is to obtain a certain degree of technology spillovers through technical training, instruction of quality standard, and other means, while foreign investors are also willing to use their own concepts and technical advantages to gradually influence and improve the technical level of domestic enterprises [17].
Some scholars have also doubted the effect of technology introduction brought by foreign capital, and their main point is that the advanced technology brought by foreign capital may also give rise to technological dependence in enterprises and fall into a "technology trap," thus constraining their own technological innovation capabilities [18]. Furthermore, foreign investors may use such measures as intellectual property protection to limit the spillovers of key core technologies $[19,20]$. However, some scholars have explained through the theory of technology suitability that the autonomy of corporate activities will not be lost as long as the advanced technology is appropriately introduced according to the specific industrial characteristics and the factor endowment structure of the country when technology is introduced [21].

In summary, we propose the research Hypothesis 2 as follows.

Hypothesis 2. Foreign shareholding has significantly positive impacts on the technology introduction.

2.3. Foreign Shareholding, Technology Introduction, and Enterprise Innovation. As mentioned above, among the ways in which foreign shareholding affects the enterprise innovation, we believe that the means of technology introduction is the most direct and effective. Thus, with the view to the path of introducing foreign advanced technology, we believe that the technology introduction has a conductive effect between FER and enterprise innovation, and it is the key to open the "black box" between foreign equity right and enterprise innovation. Foreign-funded enterprises have the mature technical knowledge and advanced management skills necessary for the successful implementation of innovation, which means that domestic enterprises can obtain innovative resources and technical knowledge by introducing foreign capital and then improve their own innovation capabilities $[22,23]$. At the same time, compared with independent $\mathrm{R} \& \mathrm{D}$, the cost of technology introduction is lower and the risks are smaller [13], which is more conducive to the realization of enterprise innovation. According to the late-developing advantage theory, once late-developing countries have successfully introduced advanced technology through foreign capital and achieved a certain technological accumulation in the process of technology introduction, they can achieve leapfrog development and upgrading innovation [24].

It is held in the neoclassical growth theory that technological innovation is the only way to achieve economic growth. In recent years, China, especially as a developing country and a large country, has increasingly highlighted the importance of technological revolution and constantly drawn experiences and lessons from the introduction of advanced technology from developed countries, with the aim to achieve technological catching-up. Foreign shareholding often directly or indirectly determines whether an enterprise introduces foreign technology. At present, the FER of domestic Chinese-foreign joint venture companies basically comes from institutional investors in developed 
countries and regions that have brought about more advanced technologies with mature life cycles and promoted product innovation and technological innovation of the invested companies. Therefore, we expect that the participation of FER will affect Chinese manufacturing enterprises through the technology level and then have a positive impact on enterprise innovation.

To summarize the above several points, it is argued in this paper that the foreign shareholding not only possesses positive impact on the enterprise innovation but also affects the enterprise innovation through the technology introduction. Therefore, the following Hypothesis 3 is proposed through summarization and extraction.

Hypothesis 3. Technology introduction is a mediating variable between foreign shareholding and enterprise innovation, and there is a conductive relationship between the three.

\section{Research Design}

3.1. Data Sources and Samples. In order to ensure the data authoritativeness and make the empirical results more accurate, this article adopts the comprehensive survey results of Chinese manufacturing companies conducted by the World Bank in 2012. The data covers the various data of full fiscal year, covering 2,700 private enterprises and 148 stateowned enterprises in China, with a time span from December 2011 to February 2013.

Through the sample selection, the following data are eliminated: (1) Question A4 of the questionnaire classifies the industry in which the enterprise is located, while the data of 148 state-owned enterprises are not marked in this item, so we have only chosen the sample data of 2700 private enterprises. (2) Nonmanufacturing enterprises are deleted according to question A4 of the questionnaire. (3) Subsidiary enterprises are deleted according to question A7 of the questionnaire. (4) The missing values of innovation, FER, technology introduction, enterprise size, enterprise age, educational background of employee, degree of informatization, international certification, and talent training are deleted. In the end, we selected a total of 1433 enterprises, involving 19 industries that include food manufacturing, textile manufacturing, and garment manufacturing.

\subsection{Variable Definition}

3.2.1. Explained Variable. Enterprise innovation behaviors mean that enterprises provide customers with new concepts, new management methods, new products, or new services through new management knowledge, technology, or new production processes $[25,26]$. According to the characteristics of research data, this paper uses new products or new service changes introduced by the company to represent the incremental innovation behaviors of enterprises.

\subsubsection{Explanatory Variable and Mediating Variable.} When designing the independent variable, combined with the contents of questionnaire, we set whether the enterprise owns shares of foreign individuals, companies, or organizations as an explanatory variable: foreign equity right (FER).

When considering the mediating variable, we have mainly considered the dimension of technology introduction. In comparison with the contents of questionnaire E6, the corresponding results are assigned to the technology introduction: "Yes" $=1$ and "No" $=0$.

To extract the effects of other factors on regression models and data analysis, the following several control variables are also set, as shown in Table 1 .

Level of employee education level: When companies focus on advancing the innovation process, talent resources are the most critical and most difficult to access temporarily. Under the same resource conditions, only those more educated people can give enterprises more impetus to innovation [27]. Thus, professional talent resources are one of the keys to enable enterprises to advance innovations in keeping with their wishes.

International certification: For enterprises, quality certification plays a role in standardizing product innovation, ensuring its systematization and independence. In general, consumers prefer to choose products with quality certification, so such products are more competitive and can thus promote the enterprise innovation [28]. Due to the backward consumption concept, most domestic consumers still tend to choose products with international certification. Therefore, whether there are a certain number of international certifications may affect the innovation process of enterprises.

Degree of informatization: The effective implementation of enterprise informatization can promote the enterprise innovation [29]. The application of information system can provide a technical platform for the sharing of enterprise information, and the degree of informatization possesses a certain impact on information dissemination and sharing and subsequently affects the enterprise innovation.

Enterprise age: As one of the important situational factors, the enterprise age is often overlooked, but in fact it is similar to the effect of enterprise size. Studies have shown that the increase in the enterprise age may make the overall enterprise style tend to be robust and conservative. At this time, the degree of influence of decision-makers on the direction of enterprise R\&D may also gradually decrease, and the innovation capability will also decline accordingly [30].

Enterprise scale: Some viewpoints hold that the larger the enterprise scale is, the more resources the enterprise can obtain. This kind of resource advantage can accelerate the elimination of old products and $R \& D$ of new products $[31,32]$. However, in general, the total number of employees represents the larger enterprise scale, so the number of employees is used to represent the enterprise scale in this paper.

Industrial characteristics: Because different industries have different levels of demand for advanced technology, if relevant innovation elements can be put into industries with demand, the effect of yielding twice the result with half the effort may be generated. If classified according to the 
TABLE 1: Variable definition.

\begin{tabular}{|c|c|c|c|c|}
\hline $\begin{array}{l}\text { Type of } \\
\text { variable }\end{array}$ & Variable name & Description of variable & $\begin{array}{l}\text { Corresponding } \\
\text { questions of } \\
\text { questionnaire } \\
\end{array}$ & Assignment of corresponding answers \\
\hline $\begin{array}{l}\text { Explained } \\
\text { variable }\end{array}$ & $\begin{array}{l}\text { Innovation behaviors } \\
\text { (innovation behaviors) }\end{array}$ & $\begin{array}{l}\text { Whether there are new } \\
\text { products or services }\end{array}$ & $\mathrm{CNo} 1$ & $" Y e s "=1 ; " N o "=0$ \\
\hline \multirow{5}{*}{$\begin{array}{l}\text { Explanatory } \\
\text { variable } \\
\text { Mediating } \\
\text { variable }\end{array}$} & FER (FER) & $\begin{array}{l}\text { Whether the enterprise } \\
\text { owns foreign equity }\end{array}$ & $\mathrm{B} 2 \mathrm{~b}$ & "Yes" = 1; "No" = 0 \\
\hline & $\begin{array}{l}\text { Technology introduction } \\
\text { (technology) }\end{array}$ & $\begin{array}{l}\text { Whether the technology is } \\
\text { imported from abroad }\end{array}$ & E6 & $" Y e s "=1 ; " N o "=0$ \\
\hline & Enterprise size (labor) & Staff size & $\mathrm{L} 1$ & $\begin{array}{l}\text { Set as a percentage of the number of } \\
\text { employees }\end{array}$ \\
\hline & Enterprise age (year) & Year of business operation & B5 & $\begin{array}{l}\text { Set as } 2012 \text { minus the "year the business } \\
\text { started" plus } 1 \text { year }\end{array}$ \\
\hline & $\begin{array}{l}\text { Educational background } \\
\text { of employee (education) }\end{array}$ & $\begin{array}{l}\text { Proportion of employees } \\
\text { with above secondary } \\
\text { school education }\end{array}$ & L9b & Set as percentage \\
\hline \multirow[t]{3}{*}{$\begin{array}{l}\text { Controlled } \\
\text { variable }\end{array}$} & $\begin{array}{l}\text { International } \\
\text { certification } \\
\text { (certification) }\end{array}$ & $\begin{array}{l}\text { Whether there is } \\
\text { international quality } \\
\text { certification }\end{array}$ & B8 & "Yes" = 1; "No" =0 \\
\hline & $\begin{array}{l}\text { Degree of } \\
\text { informatization } \\
\text { (informatization) }\end{array}$ & $\begin{array}{l}\text { Degree of enterprise } \\
\text { informatization }\end{array}$ & CNo8 & $" Y e s "=1 ; " N o "=0$ \\
\hline & $\begin{array}{l}\text { Industrial characteristics } \\
\text { (industry) }\end{array}$ & Industry dummy variable & A4 & $\begin{array}{c}\text { Classified according to the standard for } \\
\text { OECD technology intensity, with } 4 \\
\text { industries in total and } 3 \text { industry dummy } \\
\text { variables }\end{array}$ \\
\hline
\end{tabular}

standard for OECD technology intensity, the main 19 manufacturing categories involved in this paper, respectively, correspond to the four categories of high-tech industry, middle- and high-tech industry, middle- and lowtech industry, and low-tech industry and correspondingly bestow their respective dummy variables.
3.3. Model Setup. In this paper, the following multiple linear regression models are established:

$$
\begin{aligned}
\text { Innovation }- \text { behaviors }= & \alpha_{0}+\alpha_{1} \text { FER }+\alpha_{2} \text { Labor }+\alpha_{3} \text { Year }+\alpha_{4} \text { Education }+\alpha_{5} \text { Certification } \\
& +\alpha_{6} \text { Informatization }+\sum \text { Industry }+\varepsilon, \\
\text { Technology }= & \beta_{0}+\beta_{1} \text { FER }+\beta_{2} \text { Labor }+\beta_{3} \text { Year }+\beta_{4} \text { Education }+\beta_{5} \text { Certification } \\
& +\beta_{6} \text { Informatization }+\sum \text { Industry }+\varepsilon, \\
\text { Innovation }- \text { behaviors }= & \delta_{0}+\delta_{1} \text { FER }+\delta_{2} \text { Technology }+\delta_{3} \text { Labor }+\delta_{4} \text { Year }+\delta_{5} \text { Education } \\
& +\delta_{6} \text { Certification }+\delta_{7} \text { Informatization }+\sum \text { Industry }+\varepsilon .
\end{aligned}
$$

Model (1) is designed to test the impact of FER on enterprise innovation, and model (2) is designed to test the impact of FER on technology introduction. Models (1), (2), and (3) are designed to verify that FER can further promote the enterprise innovation through technology introduction; that is, technology introduction serves as the meditating variable of FER affecting the enterprise innovation.

Because the above are all tested separately, there is no existence of multicollinearity problem. In addition, the model also controls the industry effect.

Regarding the test of mediating effect, the sequential test method is adopted in this paper [33]. It can be specifically described as follows: first, there is a need to construct the initial impact of FER on enterprise innovation, that is, regression model (1), for the purpose of determining whether FER can significantly affect the enterprise innovation behaviors. When $\alpha_{1}$ is not significant, it means that there is no statistical correlation between FER and enterprise innovation behaviors, so there is no need to verify the mediating effect. When $\alpha_{1}$ is significant, there is a need to further verify the impact of FER on technology introduction and the joint impact of FER and technology introduction on enterprise innovation behaviors, that is, regression models (2) and (3). If $\beta_{1}$ and $\delta_{2}$ are significant, it means that the mediating effect 
exists indeed. Then here comes the verification of $\delta_{1}$ and $\delta_{1}$. If $\delta_{1}$ is not significant, it indicates that there exists a complete mediating effect, and if $\delta_{1}$ is significant, it indicates that there exists a partial mediating effect. It should be noted that even if $\beta_{1}$ and $\delta_{2}$ cannot simultaneously meet the significance requirements, the nonexistence of mediating effect is still unable to be determined. In this case, Bootstrap and Sobel test are still required to be conducted for further verification. For the studies in this paper, $\beta_{1}$ and $\delta_{2}$ are both significant, so there is a need to conduct Bootstrap and Sobel test.

\section{Empirical Results and Analysis}

4.1. Descriptive Statistics. The descriptive statistical results of the main variables are shown in Table 2. For innovation enterprise behaviors, the mean value is 0.427 , the minimum value is 0 , the maximum value is 1 , and the standard deviation is 0.495 , indicating that there is a relatively large gap in innovation capability between different enterprises. In terms of FER, the minimum value is 0 , the maximum value is 1 , and the average value is 0.0640 , indicating that the dynamics of foreign capital introduction are insufficient and there are fewer enterprises with FER under the economic background at that time. The employee education level reflects the quality of employees. As indicated in the table, it can be seen that the overall employee education level is on the high side, with an average of 49.74 . The enterprise scale can reflect the productivity level of enterprises from a side, with an average of 4.29 , which shows that most of our sample enterprises are small- and medium-sized enterprises. The enterprise age may hinder innovation to some extent. It can be seen from the table that some enterprises are newly established companies in 2011, while some enterprises have a long history with a maximum value of 125 , indicating that there are great differences in the business duration of different enterprises, and the impact on innovation may also be very different. The average value of international certification is 0.68 , which indicates that those enterprises in the sample generally have a relatively high level of internationalization, and most of them have international certifications. The degree of informatization may reflect the innovation foundation of an enterprise. The minimum value of this variable in the table is 0 , which means that the enterprise does not have information technology. If the maximum value is 100 , it means that such an enterprise has strong information technology and a good foundation for innovation. The average value of technology introduction is 0.221 , the minimum value is 0 , and the maximum value is 1 , proving that the overall number of companies with technology introduction at that time was relatively small.

4.2. Correlation Analysis. The main variable of Pearson correlation coefficient is shown in Table 3. From this table, it can be seen that the correlation coefficient between FER and enterprise innovation behaviors is positive, and it is significant at the level of 5\%, which indicates that FER has a positive impact on the enterprise innovation. There is a significant positive correlation between technology introduction and enterprise innovation at the level of $1 \%$. Enterprise age and degree of informatization are negatively correlated with enterprise innovation but not significantly. The educational level of employee, enterprise size, and international certification are positively correlated with enterprise innovation.

4.3. Multiple Regression Analysis. The regression results are shown in Table 4 . The regression model can verify that FER has a significantly positive impact on the enterprise innovation, and it is achieved through the path of technology introduction. Because probit model is a 0-1 type variable, it can only judge the direction of explanatory variable's impact on the explained variable and cannot give the marginal effect of the variable, so there is a need to further determine the marginal effect of each variable. The last column of Table 4 reflects the impact of the marginal change of each influencing factor on the marginal probability of FER's participation.

According to the regression results shown in the above table, the impacts of different variables on innovation performance are as follows.

First of all, in model (1), the regression coefficient of FER and enterprise innovation has a significantly positive correlation at the confidence level of $10 \%$, indicating that FER has a significantly positive impact on the enterprise innovation. In the corporate ownership structure, foreign shareholding is conducive to the realization of enterprise innovation. When further studying the paths in which foreign shareholding affects enterprise innovation, in model (2), the regression coefficient between FER and technology introduction also has a significantly positive correlation at the level of $5 \%$, indicating that foreign shareholding may urge enterprises to introduce and reform their original technologies as soon as possible. In model (3), when we put FER and technology introduction into the model at the same time, the results show that FER and enterprise innovation are positively correlated but not significantly, while the regression coefficient between technology introduction and enterprise innovation is 0.790 , which is significant at the level of $1 \%$, indicating that technology introduction plays a complete mediating effect between FER and enterprise innovation.

Second, the regression coefficient of employee education level and enterprise innovation has significantly positive correlation at the level of $5 \%$, indicating that the employee education level has a positive impact on enterprise innovation. The employee education level is directly proportional to the possibility of realizing enterprise innovation.

Third, the regression coefficient of enterprise scale and enterprise innovation has a significantly positive correlation at the level of $1 \%$, indicating that enterprise scale has a positive impact on enterprise innovation. The enterprise scale is directly proportional to the possibility of realizing enterprise innovation.

Fourth, the regression coefficient between international certification and enterprise innovation has significantly positive correlation at the level of $5 \%$, indicating that 
TABLE 2: Descriptive statistics of variables.

\begin{tabular}{|c|c|c|c|c|c|}
\hline Variable & Obs. & Mean & Std. dev. & Min & Max \\
\hline Innovation behaviors & 1,511 & 0.427 & 0.495 & 0 & 1 \\
\hline FER & 1,515 & 0.064 & 0.245 & 0 & 1 \\
\hline Educational background of employee & 1,486 & 49.74 & 28.23 & 0 & 100 \\
\hline Enterprise size & 1,515 & 4.294 & 1.234 & 1.609 & 9.68 \\
\hline Enterprise age & 1,475 & 12.9 & 7.478 & 0 & 125 \\
\hline International certification & 1,511 & 0.683 & 0.465 & 0 & 1 \\
\hline Degree of informatization & 1,510 & 27.11 & 21.06 & 0 & 100 \\
\hline Technology introduction & 1,472 & 0.221 & 0.415 & 0 & 1 \\
\hline
\end{tabular}

TABLE 3: Correlation coefficient of main variables.

\begin{tabular}{|c|c|c|c|c|c|c|c|c|}
\hline & $\begin{array}{c}\text { Innovation } \\
\text { behaviors }\end{array}$ & FER & $\begin{array}{c}\text { Educational } \\
\text { background of } \\
\text { employee }\end{array}$ & $\begin{array}{l}\text { Enterprise } \\
\text { size }\end{array}$ & $\begin{array}{l}\text { Enterprise } \\
\text { age }\end{array}$ & $\begin{array}{l}\text { International } \\
\text { certification }\end{array}$ & $\begin{array}{c}\text { Degree of } \\
\text { informatization }\end{array}$ & $\begin{array}{l}\text { Technology } \\
\text { introduction }\end{array}$ \\
\hline $\begin{array}{l}\text { Innovation } \\
\text { behaviors }\end{array}$ & 1 & & & & & & & \\
\hline FER & $0.0605^{* *}$ & 1 & & & & & & \\
\hline $\begin{array}{l}\text { Educational } \\
\text { background of } \\
\text { employee }\end{array}$ & $0.0796^{* * *}$ & 0.0393 & 1 & & & & & \\
\hline Enterprise size & $0.163^{* * *}$ & $0.0597^{* *}$ & $0.0545^{* *}$ & 1 & & & & \\
\hline Enterprise age & -0.0014 & -0.0369 & 0.0119 & $0.211^{* * *}$ & 1 & & & \\
\hline $\begin{array}{l}\text { International } \\
\text { certification }\end{array}$ & $0.119^{* * *}$ & $0.0798^{* * *}$ & $0.119^{* * *}$ & $0.337^{* * *}$ & $0.0997^{* * *}$ & 1 & & \\
\hline $\begin{array}{l}\text { Degree of } \\
\text { informatization }\end{array}$ & -0.0199 & 0.0119 & $0.335^{* * *}$ & -0.0395 & -0.0171 & $0.130^{* * *}$ & 1 & \\
\hline $\begin{array}{l}\text { Technology } \\
\text { introduction }\end{array}$ & $0.2800^{* * *}$ & $0.1758^{* * *}$ & $0.1558^{* * *}$ & $0.2011^{* * *}$ & -0.0013 & $0.1953^{* * *}$ & 0.0302 & 1 \\
\hline
\end{tabular}

*,** and ${ }^{* * *}$ represent significance at the levels of $10 \%, 5 \%$, and $1 \%$, respectively.

TABLE 4: Model regression results.

\begin{tabular}{|c|c|c|c|c|}
\hline \multirow{2}{*}{ Variables } & \multicolumn{3}{|c|}{ Probit model } & \multirow{2}{*}{ Marginal effect } \\
\hline & Model 1 & Model 2 & Model 3 & \\
\hline FER & $\begin{array}{c}0.245^{*} \\
(1.77)\end{array}$ & $\begin{array}{c}0.757^{* * *} \\
(5.24)\end{array}$ & $\begin{array}{l}0.047 \\
(0.32)\end{array}$ & 0.093 \\
\hline Educational background of employee & $\begin{array}{c}0.003^{* *} \\
(2.12)\end{array}$ & $\begin{array}{c}0.007^{* * *} \\
(4.68)\end{array}$ & $\begin{array}{l}0.002 \\
(1.17)\end{array}$ & 0.001 \\
\hline Enterprise size & $\begin{array}{c}0.153^{* * *} \\
(5.13)\end{array}$ & $\begin{array}{c}0.191^{* * *} \\
(5.61)\end{array}$ & $\begin{array}{c}0.121^{* * *} \\
(3.91)\end{array}$ & 0.058 \\
\hline Enterprise age & $\begin{array}{c}-0.009^{* *} \\
(-2.04)\end{array}$ & $\begin{array}{c}-0.010^{*} \\
(-1.88)\end{array}$ & $\begin{array}{c}-0.008^{*} \\
(-1.65)\end{array}$ & -0.003 \\
\hline International certification & $\begin{array}{c}0.194^{* *} \\
(2.44)\end{array}$ & $\begin{array}{c}0.491^{* * *} \\
(4.79)\end{array}$ & $\begin{array}{l}0.083 \\
(1.00)\end{array}$ & 0.073 \\
\hline Degree of informatization & $\begin{array}{c}-0.004^{* *} \\
(-2.13)\end{array}$ & $\begin{array}{l}-0.003 \\
(-1.27)\end{array}$ & $\begin{array}{c}-0.004^{* *} \\
(-2.03)\end{array}$ & -0.001 \\
\hline Technology introduction & & & $\begin{array}{c}0.790^{* * * *} \\
(8.82)\end{array}$ & \\
\hline Industrial characteristics & Control & Control & Control & Control \\
\hline$R^{2}$ & 0.0357 & 0.105 & 0.173 & \\
\hline$N$ & 1,433 & 1,397 & 1,395 & \\
\hline
\end{tabular}

$Z$ value is included in the bracket; ${ }^{* *}$ and ${ }^{* * *}$ represent significance at the levels of $10 \%, 5 \%$, and $1 \%$, respectively.

enterprises that have received international certification are conducive to the improvement of innovation.

Fifth, the regression coefficient between enterprise age and enterprise innovation has significantly negative correlation at the level of $5 \%$, indicating that enterprises with longer operating years tend to be more reluctant to innovate, and the main reason is that the longer the operating years of an enterprise are, the more stable this enterprise will become. For this reason, its owner is more reluctant to take the risks of innovation. 
TABLE 5: Estimation results of propensity score matching.

\begin{tabular}{lcccc}
\hline & Group with FER & Group without FER & ATT value & $T$ value \\
\hline Before matching & 0.554 & 0.426 & 0.129 & $2.41^{* *}$ \\
After matching & 0.554 & 0.444 & 0.111 & $2.05^{* *}$ \\
\hline
\end{tabular}

"Before matching" refers to the samples without the implementation of PSM. "After matching" refers to the samples after PSM matching. **indicates significance at the confidence level of $5 \%$.

Sixth, the degree of informatization is negatively correlated with the regression coefficient of enterprise innovation at the level of $5 \%$, indicating that the degree of informatization may hinder enterprise innovation, which is not the same as our hypothesis for the possible reason that when the degree of enterprise informatization is high, the work of enterprise staffs will depend on intelligent products such as computers and reduce the independent thinking of employees, which is not conducive to enterprise innovation.

As shown in the above empirical results, first of all, there is a significantly positive correlation between FER and enterprise innovation, indicating that enterprises should appropriately set up certain foreign equity in the equity structure, while vigorously introducing and utilizing foreign capital. Second, FER has an impact on enterprise innovation via technology introduction, indicating that enterprises should not only be aware of the capital and market brought by foreign capital but also fully learn and introduce advanced technology brought by foreign capital. Only in this way can the innovation and development of enterprises be promoted.

Overall, the regression results confirmed research $\mathrm{Hy}$ pothesis 1, Hypothesis 2, and Hypothesis 3.

\section{Robustness Test}

However, there are two issues to be faced when using the above empirical methods to estimate the impact of FER on enterprise innovation.

First of all, there may be selective bias in the sample enterprises. Whether an enterprise owns foreign equity is usually decided by two reasons, that is, "whether to choose on its own side (enterprise)" or "whether to choose on the other side (foreign capital)." For example, "whether to choose on its own side (enterprise)" is often manifested in some export-oriented enterprises requiring overseas interpersonal relationships and resources to open overseas markets, and they may vigorously introduce foreign capital. On the other side, "whether to choose on the other side (foreign capital)" is manifested in the scenario that foreign investors generally choose enterprises with relatively high level of performance and good operating performance. Thus, the conclusion of this study may be affected if the estimation coefficient bias caused by sample selection is not fully evaluated.

Second, there is an endogenous impact on FER, since there is always information asymmetry in enterprise research, such as nationality of corporate executives and whether they have the experience of studying abroad, in some nonpublic information. If they are calculated as omitted variables in the error term, they may cause FER to be correlated to the error term. In this case, the conclusions drawn by traditional regression method may overestimate the impact of the entry of foreign capital on enterprise innovation.

Based on the above two considerations, the propensity score matching method is used in this paper to test the robustness of this study, making the effect of FER on enterprise innovation more accurate. The core idea of this method is to find out the most similar individuals of the control group according to the observable characteristics that affect whether there is FER or not, under the premise that the group with FER and the group without FER are not randomly selected and led to biased estimation results. This can not only remove endogenous problems caused by unobservable factors but also control some observable heterogeneity factors and eliminate endogenous problems caused by self-selection in nonrandom trials [34].

We adopted the kernel matching to match data, so as to find out the innovation differences between the group with FER and the group without FER. The regression results are shown in Table 5.

As shown by Logit's regression result, the estimated value of ATT is 0.111 , and the corresponding $t$ value is 2.05, which is greater than the critical value of 1.96 , so the result is significant. In addition, after the matching, comparisons are made with regard to the result of matching before matching; it can be found that the logarithms of average innovation behaviors corresponding to the group with FER and the group without FER are 0.554 and 0.426 , respectively, and it is significantly different from zero at the level of $5 \%$, indicating that the enterprise innovation activities of the enterprises with FER are 0.128 higher than those of the group without FER. After matching, the logarithms of the average innovation behaviors of the groups with and without FER are 0.554 and 0.444 , respectively, with a difference of 0.11 . This means that, after considering the selective bias and endogenous problems of FER in enterprises, the effect of FER on enterprise innovation becomes obviously smaller, and ignoring the selective bias and endogenous problems of FER in enterprises may cause serious overestimation of the impact of FER on enterprise innovation. The standard deviations of most variables are greatly reduced, indicating that they are completely acceptable, and the $t$-test results do not reject the original hypothesis that there is no systematic difference between the treatment group and the control group.

In summary, the research conclusions obtained in this paper do not change due to the change of empirical method, and the research results have a certain degree of robustness. After putting the sample selective bias and endogenous problems under control, the empirical results are still valid. 


\section{Conclusions and Discussion}

In this paper, through the screening of the survey data regarding the manufacturing sector of China enterprises conducted by the World Bank in 2012, we have empirically explored the impact of FER on the enterprise innovation and analyzed how foreign shareholding affects the enterprise technology introduction and subsequently affects the enterprise innovation. After putting endogenous problems under control, the research conclusions are still robust. The research conclusions of this paper mainly comprise the following two points.

First of all, research shows that foreign shareholding in general has a positive impact on the innovation of Chinese manufacturing companies. Thus, we should further develop our own capability of utilizing foreign capital to promote the enterprise innovation, so that FER can play a better role on the path of Chinese companies in the process of accelerating innovations. We believe that there is a need to continue expanding the scope of opening up, further guide enterprises to reasonably introduce foreign capital through preferential policies and supports, properly encourage foreign ownership in the corporate shareholding structure, and allow most enterprises to enjoy the dividends from foreign shareholding.

Second, when exploring the specific path of foreign shareholding affecting enterprise innovation, we have further verified and drawn the conclusion that technology introduction plays a complete mediating role in FER and enterprise innovation. Enterprises should encourage foreign investors to participate in enterprise management, especially the management of advanced technologies, introduce advanced foreign technologies, and stimulate the enterprise innovation. In addition, enterprises should digest (absorb), reinnovate, and accelerate the improvement of their own technology level and improve their independent innovation capabilities on the basis of introducing technology.

There are some limitations in this study. First of all, due to the limitation of data availability, this paper uses the data of the World Bank in 2012. From the perspective of time, the effectiveness of the conclusions may be lacking. In addition, the industry focus selected in this paper is manufacturing enterprises. For other industries that also play an important role in the development of national economy, this study does not get them involved, and it is hoped that the expansion of industry scope will be made in follow-up studies.

\section{Data Availability}

The experimental data used to support the findings of this study may be released upon application to the World Bank, which can be contacted at https://microdata.worldbank.org/ index.php/catalog/1559.

\section{Conflicts of Interest}

The authors declare that there are no conflicts of interest regarding the publication of this paper.

\section{Acknowledgments}

This work was supported in part by the National Natural Science Foundation of China (71673145).

\section{References}

[1] P. Lin, Z. Liu, and Y. Zhang, "Do Chinese domestic firms benefit from FDI inflow?: evidence of horizontal and vertical spillovers," China Economic Review, vol. 20, no. 4, pp. 677691, 2009.

[2] C. Kui-Yin and P. Lin, "Spillover effects of FDI on innovation in China: evidence from the provincial data," SSRN Electronic Journal, vol. 15, no. 1, pp. 25-44, 2003.

[3] A. Kokko, "Technology, market characteristics, and spillovers," Journal of Development Economics, vol. 43, no. 2, pp. 279-293, 1994.

[4] B. Dachs and B. Ebersberger, "Does foreign ownership matter for the innovative activities of enterprises?" International Economics and Economic Policy, vol. 6, no. 1, pp. 41-47, 2009.

[5] W. Keller, "Geographic localization of international technology diffusion," American Economic Review, vol. 92, no. 1, pp. 120-142, 2002.

[6] H. Görg and D. Greenaway, "Much ado about nothing? Do domestic firms really benefit from foreign direct investment?" The World Bank Research Observer, vol. 19, no. 2, pp. 171-197, 2004.

[7] B. J. Aitken and A. E. Harrison, "Do domestic firms benefit from direct foreign investment? Evidence from Venezuela," American Economic Review, vol. 89, no. 3, pp. 605-618, 1999.

[8] H. Luong, L. F. Moshirian, and B. X. ZhangTian, "How do foreign institutional investors enhance firm innovation?" Journal of Financial and Quantitative Analysis, vol. 52, no. 4, pp. 1449-1490, 2017.

[9] M. Acquaah, "Managerial social capital, strategic orientation, and organizational performance in an emerging economy," Strategic Management Journal, vol. 28, no. 12, pp. 1235-1255, 2007.

[10] H. Yli-Renko, H. J. E. Autio, and H. J. Sapienza, "Social capital, knowledge acquisition, and knowledge exploitation in young technology-based firms," Strategic Management Journal, vol. 22, no. 6-7, pp. 587-613, 2001.

[11] P.-H. Hsu, X. Tian, and Y. Xu, "Financial development and innovation: cross-country evidence," Journal of Financial Economics, vol. 112, no. 1, pp. 116-135, 2014.

[12] S. B. Choi, B. I. Park, and P. Hong, "Does ownership structure matter for firm technological innovation performance? The case of Korean firms," Corporate Governance: An International Review, vol. 20, no. 3, pp. 267-288, 2012.

[13] M. I. Kafouros and N. Forsans, "The role of open innovation in emerging economies: do companies profit from the scientific knowledge of others?" Journal of World Business, vol. 47, no. 3, pp. 362-370, 2012.

[14] M. Guadalupe, C. O. Kuzmina, and C. Thomas, "Innovation and foreign ownership," American Economic Review, vol. 102, no. 7, pp. 3594-3627, 2012.

[15] S. Claessens and N. V. Horen, "Foreign banks: trends and impact," Journal of Money, Credit and Banking, vol. 46, no. 1, pp. 295-326, 2014.

[16] G. Sourafel, G. Yundan, and G. Holger, "Foreign direct investment, access to finance, and innovation activity in chinese enterprises," The World Bank Economic Review, vol. 22, no. 2, pp. 367-382, 2003. 
[17] B. S. Javorcik, "Does foreign direct investment increase the productivity of domestic firms? In search of spillovers through backward linkages," American Economic Review, vol. 94, no. 3, pp. 605-627, 2004.

[18] L. Yu, Z. H. Li, and Y. Duan, “Technology imports and selfinnovation in the context of innovation quality," International Journal of Production Economics, vol. 214, pp. 44-52, 2019.

[19] R. Smeets and A. De Vaal, "Intellectual property rights and the productivity effects of MNE affiliates on host-country firms," International Business Review, vol. 25, no. 1, pp. 419-434, 2016.

[20] X. Fu and Y. Gong, "Indigenous and foreign innovation efforts and drivers of technological upgrading: evidence from China," World Development, vol. 39, no. 7, pp. 1213-1225, 2011.

[21] D. Acemoglu, P. Aghion, and F. Zilibotti, "Distantce to frontier, selection and economic growth," Journal of the European Economic Association, vol. 4, no. 1, pp. 37-74, 2002.

[22] V. Z. Chen, J. Li, and X. Zhang, "Ownership structure and innovation: an emerging market perspective," Asia Pacific Journal of Management, vol. 31, no. 1, pp. 1-24, 2014.

[23] C.-J. Chen, B.-W. Lin, Y.-H. Lin, and Y.-C. Hsiao, "Ownership structure, independent board members and innovation performance: a contingency perspective," Journal of Business Research, vol. 69, no. 9, pp. 3371-3379, 2016.

[24] M. Abramovitz, "Catching up, forging ahead, and falling behind," The Journal of Economic History, vol. 46, no. 2, pp. 385-406, 1986.

[25] T. M. Amabile and N. D. Gryskiewicz, "The creative environment scales: work environment inventory," Creativity Research Journal, vol. 2, no. 4, pp. 231-253, 1989.

[26] P. Kirk and A. Afuah, Innovation Management: Strategies, Implementation and Profits, Oxford University Press, Oxford, England, 2004.

[27] S. Harrison and P. H. Sullivan, "Profiting from intellectual capital," Journal of Intellectual Capital, vol. 1, no. 1, pp. 33-46, 2000.

[28] C. Shu, Y. Xiao, and S. Gao, "How green management influences product innovation in China: the role of institutional benefits," Journal of Business Ethics, vol. 133, no. 3, pp. 471-485, 2016.

[29] N. Matteucci and A. Sterlacchini, ICT, R\&D and Productivity Growth: Evidence from Italian Manufacturing Firms, Università Politecnica Delle Marche, Ancona, Italy, EPKE Working Paper, 2004.

[30] J. F. Reinganum, "Innovation and industry evolution," The Quarterly Journal of Economics, vol. 100, no. 1, pp. 81-99, 1985.

[31] I. Booyens, "Are small, medium- and micro-sized enterprises engines of innovation? The reality in South Africa," Science and Public Policy, vol. 38, no. 1, pp. 67-78, 2011.

[32] S. Lee, B. G. Park, and J. Park, "Open innovation in SMEs-An intermediated network model," Research Policy, vol. 39, no. 2, pp. 290-300, 2010.

[33] R. M. Baron and D. A. Kenny, "The moderator-mediator variable distinction in social psychological research: conceptual, strategic, and statistical considerations," Journal of Personality \& Social Psychology, vol. 51, no. 6, pp. 1173-1182, 1986.

[34] L. T. Kane, T. Fang, M. S. Galetta et al., "Propensity score matching: a statistical method," Clinical Spine Surgery, vol. 33, no. 3, 2020. 